\title{
THE HISTORICITY AND THE TRADITION OF PESANTREN BENDA KEREP
}

\author{
Kairin \\ IAIN Syekh Nurjati Cirebon (khoiruahmad@gmail.com)
}

\begin{abstract}
In fifteenth century, Islam had strived in Java. Mainly in West Java, the islamic courts - Kraton-kraton - of Cirebon had played an enermous role at this early development of Islam. Furthermore, the second former ruler of Kraton Ciebon, Syekh Syarif Hidayatullah or well known as Sunan Gunung Djati, was one of Wali Songo (the nine sints) in Java, whose descents then spreaded to the rural village around the court to build pesantrens. Therfore, between the 19th and 20th centuries, Cirebon was one of the centres of pesantren in Java by the establishment of some pesantrens. Pesantren Benda Kerep is, instead of Pesantren Buntet, Gedongan, and Kempek, one of the inheritances of the islamic court, Kraton Cirebon. Unlike other traditional pesantrens in Cirebon, It has kept its tradition, so that it now becomes the fossil of ancient civilisation of Cirebonese. However, it should eventually receive some ways of alternation.
\end{abstract}

Keywords: Tradition, Pesantren, and alternation

\begin{abstract}
Abstrak
Pada abad kelima belas, Islam telah mulai masuk lebih dalam di Jawa. Terutama di Jawa Barat, Kesultanan Islam Cirebon telah memainkan peran yang sangat penting pada perkembangan awal Islam ini. Selanjutnya, pendahulu penguasa kedua Kraton Cirebon, Syekh Syarif Hidayatullah atau yang dikenal dengan Sunan Gunung Djati, adalah salah satu dari Wali Songo (sembilan wali) di Jawa, yang keturunannya kemudian menyebar ke desa sekitar kesultanan untuk membangun pesantren. Oleh karena itu, antara abad 19 dan 20, Cirebon adalah salah satu pusat pesantren di Jawa dengan banyaknya jumlah pesantren disana. Pesantren Benda Kerep ini, merupakan salah satu warisan yang masih tersisa dari Kesultanan Islam Kraton Cirebon tersebut. Tidak seperti pesantren tradisional lainnya di Cirebon, tradisi di pesantren ini tetap terjaga hingga sekarang, dan menjadi sisa-sisa peradaban kuno orang Cirebon. Meski demikian, tradisi tersebut akhirnya harus menerima beberapa penyesuaian tertentu karena adanya perubahan-perubahan yang terjadi di tengah masyarakat.
\end{abstract}

Kata Kunci: Tradisi, pesantren, dan alternasi

\section{A. Introduction}

When speaking about Benda Kerep we probably do not believe that in the city zone strived an unpretentious, traditional and isolist pesantren as Benda Kerep. Its strategic position and geography as a part of the city of Cirebon preferred to keep the local culture rather than following the gobalisation stream. It is also well known as an ancient fossil of traitional society in Cirebon which is still alive in modern and techology era. The principles and norms which it held indicates that it is hidden from the nasty outside cultures. The heterogent society of Benda Kerep does not dispel their 
solidarity in preserving the principles and continious traditions inherited from generation to generation. Such a thing makes the writer interested to deeperly explore Pesantren Benda Kerep and be focused on research in its historic tradition and alternation.

The presence of Pesantren Benda Kerep, as one of the oldest pesantren in Cirebon, is related to the political escalation of Kesultanan Cirebon. The fuonding father of pesantren benda kerep, Kiai Sholeh Zamzami, was indeed one of the descents of Kraton Kanoman who along with his family leaved the court due to the intervantion of Ducth-Colonial-Government into Kraton bureaucracy. After Panembahan Ratu II or Panembahan Girilaya dead in 1662, the dominance of Cirebon was divided toward three princes : The prince Martawijaya, The prince Kartawijaya, and Pangeran Wangsakerta. The circumtance of divided Cirebon made Prince Martawijayah desired to reunite all regions of Cirebon. $\mathrm{He}$, consequently, asked help of DucthColonialist to grab the power of his relatives. Then came the agreement between the court and the colonialist that Cirebon should have been a part of colonialist authority, and every court's policy must have been suitable to the colonialist desire. ${ }^{1}$

This situation made the court's family who did not agree with the colonialist leaved it out. They built the cottages as a learning place for people in the rural area of Cirebon. one of them was Kiai Sholeh, the founding father of Pesantren Benda Kerep in Argasunya, Harjamukti, Cirebon which is very famous with its keeping tradition and unique.

\section{B. The Establishment of Pesantren Benda Kerep}

The history of pesantren Benda Kerep is an interply to the power political escalation of the islamic court in Cirebon in seventeenth and Eighteenth centuries. After panembahan Ratu, the ruler of Cirebon Court, was replaced by Panembahan Girilaya who passed away in jail of Islamic Mataram Kingdom. The kingdom of Cirebon was divided into three regions of court: The Prince Martawijaya reigned in Kasepuhan Court, the prince Kartawijaya ruled the Kanoman Court and the last Prince wangsakerta sat on the throne of Kaprabonan Court. Then, in order to reunite the power of kingdom Cirebon and to influence the already

\footnotetext{
${ }^{1}$ Amman N. Wahju, Sajarah Wali Syekh Syarif Hidayatullah Sunan Gunung Jati (Naskah Kuningan), Bandung: PUSTAKA, 2010, p. 89.
} 
divided regions, the government of Dutch Colonialist came into the politic jails and intervented every roles in the body of courts. Such a case made many family of the courts choosed to hang out from courts and built a boarding school in rural area and so did Kiai Sholeh, the founder of Pesantren Benda Kerep, and his family go away from Court to build Pesantren in Cimeuweuh, a village of Kelurahan Argasunya Kecamatan Harjamukti Cirebon in $1862 .^{2}$

The land of Benda Kerep was actually part of the Kanoman Court and so was the intention of Kiai Sholeh to build pesantren on that place was the order of Kiai Anwaruddin as his uncle and friend as well. Before Kiai Sholeh established Pesantren Benda Kerep, he had along with Kiai Anwaruddin already built a pesantren and stayed in Situ Patok, Mundu. He then moved to Gegunung, Sumber and made another pesantren. ${ }^{3}$

Through the long ride to Gegunung, Kiai Anwaruddin acquired a clue that Kiai Sholeh who was highly tough in sufism had to move to Cimeuweuh once he was needed to conquer the unseen

${ }^{2}$ An interview with Kiai Miftah, The guidence of Pesantren Benda Kerep, on February 22nd, 2015. at $09: 30 \mathrm{am}$.

${ }^{3}$ Ibid. influences around it. Kiai Anwarudin thought that Sumber would become the centre of Cirebon government and it would give bad impact to his family and generation as well as his sufism. It was, morever, unapropiate to hide the family from crowd.

Coming from this clue, Kiai Sholeh and Kiai Anwaruddin went to Cimeuweh with the intention to conquer the land from mysterious intruption. Having arrived to that place, they both asked Allah help and safety from the hidden disturbtion. By the karomah ${ }^{4}$ of Kiai Sholeh and Kiai Anwarudin the unseen settlers around Cimeuweuh hanged out and were submitted. ${ }^{5}$

The village cimeuweuh was highly popular for its eerieness. Besides, according to Kiai Miftah, the term cimeuweuh came from the word "ci-eweuh" which means to be nothing because whoever came in to the village - which is still an untouched wood then - would disappear and never came back. ${ }^{6}$ Untill Kiai Sholeh came to fall unseen creatures living in the wood out.

\footnotetext{
${ }^{4}$ A peculiarity given to special one.

http://dalilaahsanah.blogspot.com/2011/06/sejar ah-singkat-benda-kerep.html

${ }^{6}$ An interview with Kiai Miftah, The guidence of Pesantren Benda Kerep, on February 22nd, 2015. at $09: 30 \mathrm{am}$.
} 
In the other hand, based on the data collected from Kiai Mifth, a son of Kiai Faqih, ${ }^{7}$ on the prosess of conquerring, the unseen in cimeuweuh were conquered and might went out from that place except two creatures : the mysterious tiger and snake. They made a deal with Kiai Sholeh that they should always protect and take care of the grand-sons of Kiai Sholeh. The information was corrected by Kiai Muhammad Nuh, a son-in-law of Kiai Hasan bin Kiai Abu Bakar bin Kiai Sholeh. Furthermore, according to Kiai Muhammad Nuh up to the present the people of Cimeuweuh Benda Kerep now - often see the presence of the mysterious white tiger and a massive snake around Benda Kerep. ${ }^{8}$

In short, after the land of Cimeuweh was able to be conquered, the news of its concuest arrived to Sultan Zulkarnaen, the ruling regime of Kanoman Court then, having heared the good news, the land of cimeuweuh, still belonged to him, was granted by him to Kiai Sholeh as long as it would be used to be the centre of learning islamic knowledge and the preaching of the Islam religion. It made a familiar relationship between Benda Kerep

${ }^{7}$ A grand son of Kiai Sholeh.

${ }^{8}$ Ibid. and Kanoman Court getting tighter and tighter. ${ }^{9}$

By the time, Kiai Sholeh started to settle in cimeuweuh along with his first wife nyai Menah from Pekalongan. On the first days in cimeuweuh he built kranggon, like a cottage as a ressidance. Because there were and are available trees of Benda spreaded across the vllage cimeuweuh, people around it then named the Place Benda Kerep. ${ }^{10}$

The presence of Benda Kerep as a new face of Cimeuweuh had certainly attracted various intentions from Cirebon society. Morever there was a noble person having high standard of islamic knowledge and standing with sublime attitude as well as tightly handling the principes of aqidah. As a result, many cireboneses especially those from around Benda Kerep intended to learn and study there. It then made Benda Kerep crowder due to the students coming from out of Cirebon as well. Hence, Kiai Sholeh felt that he should have grounded the knowledge of Islam more serriously. ${ }^{11}$ Therfore, The cottage where Kiai Sholeh and his wife lived was after that renovated to give more

http://dalilaahsanah.blogspot.com/2011/06/sejar ah-singkat-benda-kerep.html

${ }^{10}$ Ibid

${ }^{11}$ Ibid 
comfortness. Kiai Sholeh By the help of his students built the haouse which would be the first house in Benda Kerep. It still stands up on the ground with little renovaton and becomes the house of Kiai Fakih, the grand son of Kiai Sholeh from Kiai Abu Bakar. ${ }^{12}$

In the era of dutch-colony, Pesantren Benda Kerep was never touched by Ducth since when they came to invade, It by the permission of god became invisible. The only did the Ducths see was not a land but the sea. ${ }^{13}$ Even though their land was not reached by Ducth-colony, it did not make the family of Kiai Sholeh careless of the colonialisation. As Kiai miftah said that one of his uncle, Kiai Mas'ud, grand-son of Kiai Sholeh from Kiai Muslim, was involved in the war of independence of Republic Indonesia. ${ }^{14}$

Just like other traditional pesantrens in Cirebon, Pesantren Benda Kerep has long applied the method and educational system of traditional pesantren. The forms of teaching like sorogan, wetonan and ceramah are very common to be

\section{${ }^{12}$ Ibid}

13

http://dalilaahsanah.blogspot.com/2011/06/sejar ah-singkat-benda-kerep.html

${ }^{14}$ An interview with Kiai Miftah, The guidence of Pesantren Benda Kerep, on February 22nd, 2015. at $09: 30 \mathrm{am}$. conducted here. The following will expand on how the sorts of teaching in the system of traditional pesantren education are practiced in Pesantren Benda Kerep from time to time.

The first is system wetonan, the main method in Pesantren education. The system wetonan applied is a lecturing system, where ustadz, the teacher of pesantren, reads a book while his students give the meaning and write some explanations needed on the book they examine. Zamakhsyari Dhofier furthermore explains that the method wetonan is a teaching on which the teacher reads, translates, explains, and reviews the Arabic books of Islam while a group of Santri listen to him/her. ${ }^{15}$ The teaching prosess of wetonan in pesantren Benda Kerep used the salaf books correlated to contemporerary phenomenom, namely, from the salaf books examined, they then expand and correlate it to be suited with the present age which can facilitate the students to understand the content of the books. The system can be divided into some activities : (1) Wetonan after praying ( Shubuh, Dzuhur, and Isya), (2) The speedy teching at certain time and (3) The

\footnotetext{
15 Mujamil Qomar, Pesantren Dari Transformasi Metodologi Menuju Demokratisasi Institusi, (Jakarta: Penerbit Erlangga, 1996), hlm 143.
} 
taching in month Ramadhan. The islamic books examined in daily implemented wetonan are Tafsir Jalalain, Shahih Bukhori, Sirojut Thalibi, Tanbihul Ghafilin and so on.

Secondly, the system sorogan, it is practiced in Pesantren Benda Kerep is the system of "an Active santri". The student reads an islamic book in front of ustadz, then the ustadz asked some issues involved in the content having been read. The ordinary teaching system by sorogan is the learning quran for beginner and Islamic salaf books for intermediate students. The books taught by this method is Safinatunnajah (emphasizing on comprehensing nahwu sharaf), Sulam Taufiq (stressing at the understanding of text) dan Fathul Qorib (presuring on concepting the text dan masail waq'iyyah).

Beside as a medium to obtain a deep understanding of Islamic books (kitab kuning), the implementation of sorogan is also made to be an arena of developing the attitudes of santri and ustadz. The teaching held which used the system of sorogan required all students to sit circle while listening to Ustadz or kiai sitting in the middle. Both students and teacher sit on the ground in an open chamber.

Lastly, the lecture system, this is highly infrequently found and usually explained by kiai or ustadz in certain moments. The same system in Pesantren Benda Kerep is applied once a week by paying attention to muidloh hasanah or tausiyah at Thursday night before doing tahlilan. The content of the Mauidloh Hasanah is decleared by telling a story that it is supported by citational reference from Koran.

The curriculum available in Benda Kerep is basicly not far different from that in other pesantrens, since the islamic books utilized and the teaching method applied are similar to those taught by them. nevertheless, Pesantren Benda Kerep absolutely insists on not putting seculer lessons into its pesantren curriculum.

Following is the schedule of teacing and daily activities of students in Pesantren Benda Kerep ${ }^{16}$ :

1. 03.00-04.30 : Prayer qiyamul lail (praying at midnight)

2. 04.30-05.30: Shubuh prayer together

3. 07.00-08.30 : Learning

Kitab Kuning

$$
\text { 4. 08.30-12.45: Taking a }
$$

rest

${ }^{16}$ An interview with Kiai Miftah, The guidence of Pesantren Benda Kerep, on February 22nd, 2015. at $09: 30 \mathrm{am}$. 
5. 12.45-14.00 : Learning Kitab Kuning

6. 14.00-15.00 : Taking a

rest

7. 15.30-17.00 : Learning Kitab Kuning

8. 17.00-18.00 : Taking a

rest

9. 18.00-19.00 : Maghrib

prayer and learning Koran

10. 19.30-21.30 : Isya prayer and learning Kitab Kuning

21.30-03.00 : Nightly sleeping

The activities of students and people of Benda Kerep are mostly used to learn. No day is without teaching. Besides, they are demanded to know about the grammar of Arabic and to remember Koran as well as hadits. Out of these schedules they are sunk below a ritual of tarekat or riyadloh. In addition, every Friday students are free from any teaching activity. From thrusday night, the agenda of reciting the holy Koran is replaced by doing tahlilan, yasinan, and marhabanan in mosque of Pesantrren.

Regarding the traditions of religious ritual developing in Pesantren Benda Kerep, it was related to the flowering of islamic missionary. The use of sufism tradition as a medium of preacing has been proved to attract rural people to keep and lift the piety to god. It could be seen that one of tarekat mu'tabaroh (accepted tarekat for traditional moslems ${ }^{17}$ ) in Benda Kerep has still been thriving : tarekat syatariah.

If the mursyid, a teacher of tarekat, genealogy of this tarekat is furrowed, one of the figure correlated to this track is the founder of Pesantren Benda Kerep, Kiai Sholeh. Tarekat syatariah had established in pesantren Benda Kerep through the link of Kiai Anwaruddin (Kiai Kriyan), the student of Kiai Asy'ari from pesantren Kaliwungu Kendal, Central Java . Kiai Anwaruddin himself was in addition son-in law of Kiai Muta'ad, father of Kiai Sholeh, from Buntet Pesantren. These are the spiritual genealogy of tarekat syatariah $^{18}$ :

Nabi Muhammad

Ali bin Abi Thalib

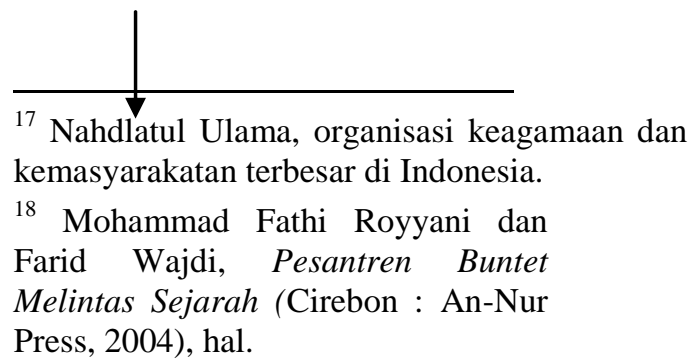


Husein

Hasan Khirqani

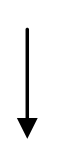

Zain al-A'bidin

Hadaqly
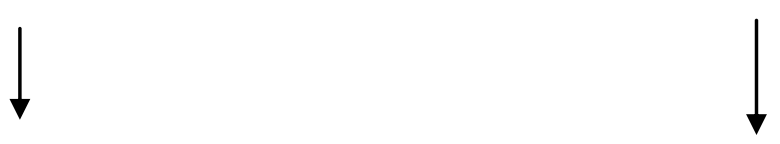

Al-Baqir

Ja'far Shadiq
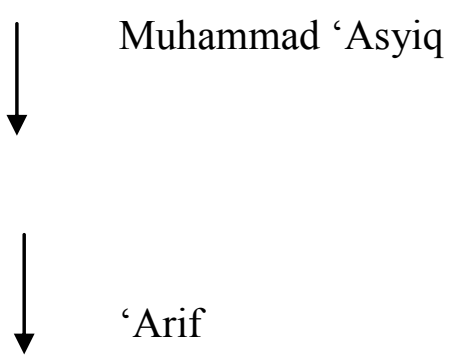

Abi Yasin Al-Busthomi

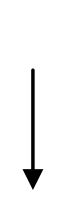

Muhammad Maghribi

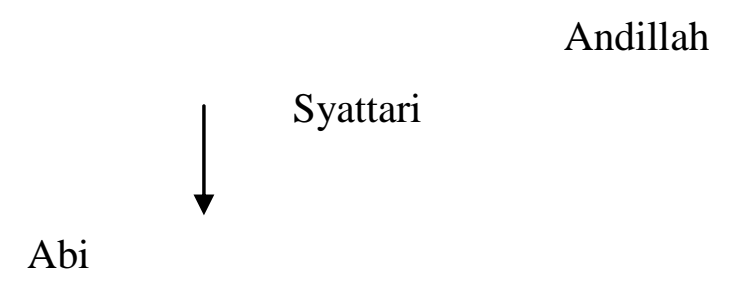

Qadhi Syattari

Al-

Mudhafar Turki at-Tusi

Hidayatillah Sarmat

Tamaddun, Vol. 5, No. 2, Juli - Desember 2017 
Hudhari

Thahir Madani

Al-Ghawth

Sibghatillah

Ahmad

Muhammad

Anwaruddin

Syanani

Kriyani (Kiai Kriyan)

Kiai

Ahmad Qasyasyi

Malla

Kiai Asy'ari

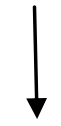

Sholeh Zamzami

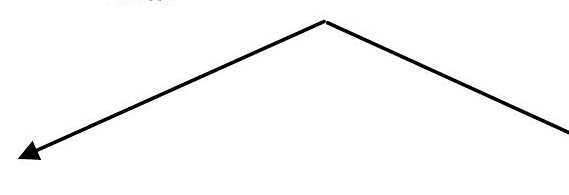

Ibrahim al-Mu'alla

$$
\downarrow \begin{aligned}
& \text { Kiai Abdul Jamil } \\
& \text { Kiai Muslim } \\
& \text { (Buntet Pesantren) }
\end{aligned}
$$

Thahir

Kiai abu Bakar

Ibrahim 
Kiai Faqih

Kiai Hasan

Kiai Anwaruddin as a founder of tarekat syatariah in Buntet pesantren was given an authority by Kiai Asy-ari Kaliwungu to be a mursyid. The accepting authority to him can be traced through the spiritual genealogy of Kiai Anwaruddin. He, hence, was the 29th guidence of tarekat syatariah, and so did Kiai Sholeh as a his conggregant become the 30th guidence or mursyid of this tarekat according to the genealogically spiritual chain to the prophet Muhammad. ${ }^{19}$

Kiai Sholeh inherited the tarekat to Kiai Muslim, Kiai Abu Bakar, Kiai Faqih, Kiai Hasan, and Kiai Miftah who have been allowed to recruit their own conggregants. It could be said that there is a sort of a certain autonomy for Kiai Sholeh's descents to recrut conggregant of

19 A. G. Muhaimin, The Islamic traditions of Cirebon : ibadat and adat among Javanese muslims, (Canberra : ANU E Press, 1995), p. 250-251. tarekat syatariah. As a result, the existance of this has still been strong and even positively flowering. ${ }^{20}$

Futhermore, from the routines of santri in pesantren Benda Kerep, it seems that they are accustumed to practicing riyaloh like fasting on Monday and thrusday and mujahadah, chanting holly words. The habbits became a unique tradition of the pesantren which even could survive untill now. Further, On its history, the flowering of riyadloh practicing in Benda Kerep from the past untill recently has never changed. However, the intensity and commitment to applicate the riyadloh performing experienced a little decline.

As Kiai Miftah said that the earlier santri of Benda Kerep were popular for their apprehension, Monday-thrusday fasting habit, and diligently keeping worship. Along with the alternation of age, the students coming to benda kerep are more various, some of whom are unobidient to maintan the roles and norms. Morever, according to senior student, Farihin, morality and tradition degradation in Benda Kerep are mostly affected by the temporary students. The various obedience level and and background yields the kinds of problems. Therfore the

\footnotetext{
${ }^{20}$ Ibid, p. $250-251$.
} 
riyadloh performed by students of benda kerep from time to time experienced lowering intensity.

\section{Kiai Sholeh Zamzami And His Genealogy}

Genealogicly Kiai Sholeh is still the descent of Syekh Syarif hidayatullah, well-known as Sunan Gunung Djati, the former ruler of Cirebon Court. Following is the genealogy of Kiai Sholeh ${ }^{21}$ :

Syarif Hidayatullah

(Sunan Gunung Jati)

Pangeran Pasarean

Pangeran Dipati

Pangeran Dipati

Pangeran Ratu

Kang seda ing Girilaya

21 Mohammad Hisyam Manshur, Sekilas Lintas Buntet Pesantren Mertapada Kulon Cirebon (Buntet Pesantren, Cirebon, 1973), p. 83-84.
Pangeran Sutajaya

Kang seda ing Tambak

Pangeran Sutajaya

Kang seda ing Grogol

Dalem Kebon ing Gebang

Dalem Anom / Sultan Senapati

Pangeran Sutajaya ing Gebang

Kocap Sultan Matangaji

Raden Bagus

Raden Punjul

Raden Ali

Raden Muhammad Nuruddin

Raden Muridin 
KH. Muta'ad

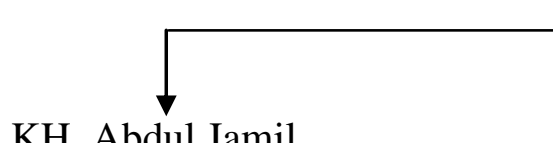

KH. Abdul Jamil

KH. Sholeh Zamzami

Kiai Sholeh is predicted to live at the same age as did Kiai Asy'ari, father of Kiai Hasyim As'ari, founder of Pesantren Tebu Ireng (1826). through a magical power of Kiai Sholeh, Benda Kerep which had been full of mystic sensation seemed glowing with the light of Islam shining at every corner on the village. The prosess of teachimg Islam was well conducted where the verses of Koran were recited in core of the jungle. The applied islamic teaching which always touched great value, attitude, and morality tightly adhered on every single Benda Kerep citizens.

However, on the other side, Kiai Sholeh himself was disturbed as if he felt empty that somthing lost in his life. This restlessness began to appear when realizing that his only wife did not get pregnant yet whereas the presence of sons and grandsons is highly important to advance the regeneration of relay race Kiai Sholeh struggle in establishing Islamic law in Benda Kerep. By so long reflecting escorted by prayers and his wife's blessing, he eventually took a decision to again get merried. It was then Nyai Merah from Manafizaha who was marreid as the second wife by Kiai Sholeh. ${ }^{2}$ From the result of this marriage, the hopes of Kiai Sholeh to have generation Apparently came true. Nyai Merah gave him three children : two sons and a daughter. The males are Kiai Muslim and Kiai Abu Bakar and the only female is Nyai Qona'ah.

Regarding the legacies of the next generaton, Kiai Muslim as the first child had seven sons, some of whom are Kiai Kaukab, Kiai Fahim, Kiai Fatin, Kiai Mas'ud, Kiai Zaeni Dahlan, and Kiai Muhtadi who have all been living in Benda Kerep as well as Kiai Sayuti who lived in Cibogo. In addition, from Kiai Abu Bakar, the second son of Kiai Sholeh, according to the information acquired that he had two sons : Kiai Hasan, the father-in-law of Kiai Muhammad Nuh and Kiai Faqih, the biological father of Kiai Miftah, who have all been living in Benda Kerep. Looked at above genealogies, it could be certain that the both sons of Kiai Sholeh and their descents mostly lived in Benda Kerep and went on Kiai Sholeh's dedication.

\footnotetext{
${ }^{22}$ KH Faqihudin (salah satu pengurus ponpes Benda Kerep), dalam Blog resmi Benda Kerep; http://dalilaahsanah.blogspot.com/2011/06/sejar ah-singkat-benda-kerep.html, diunduh 22 Maret 2015, 16:22 wib.
} 
The little family of Kiai Sholeh and Nyai Merah strived to have been a large family, which each child then stood alone and separated to build their own family. This new generation family more and more enlievened the whole activities in Benda Kerep, which made the people around attracted to join gathering and studying in Pesantren Benda Kerep. Besides, to celebrate the establishment of Pesantren Benda Kerep and to give prayer to dead family of Kiai Sholeh, people organize the haul ceremony which is held on Dzulhijjah, 12th, 13th, 14th or every year after the day of Idul Adha.

\section{The Tradition of Benda Kerep}

\section{Tradition of Muludan}

The biggest agenda in ceremonies of Islamic great days in Pesantren Benda Kerep is the ceremony of Maulid Nabi Muhammad (the commemoration of Muhammad's birth day) on every Rabiul $\mathrm{Awal}^{23}$ 12th. In this celebration, the village of Benda Kerep is as if celebrating people party. Every single house prepares "berkat", a sort of package for those coming to Tahlilan ceremony. It even can make a mob, probably up to

\footnotetext{
${ }^{23}$ The fourth month in islamic calender.
}

thousands of people load the mosque and the yard of pesantren.

On its development, the history of the celebration of Maulid Nabi in Benda Kerep ${ }^{24}$ was only done in the area of pesantren mosque. Along with the development of Benda Kerep zone, mainly those who came in due to political escalation in the era of an old order (1965), ${ }^{25}$ more and more people intended to participate in the agenda of maulid. Furthermore, many of those new comers became enterpreuners and made small businesses in Jakarta which elevated the economic condition of people around Benda Kerep. It thus contributed to make the maulid ceremony crowder. ${ }^{26}$

In 1988, when electricity came to Benda Kerep, the celebration of maulid was not only conducted in mosque but also in houses of citizens. It could happen in some days since every house wanted to take part in providing the "berkats", so the implementation of maulid should have been divided into 10

\footnotetext{
${ }^{24}$ Dalam perayaan maulid nabi di Benda Kerep, agenda acara utamanya adalah pembacaan barjanzi dan pembacaan tahlil untuk mendoakan para sesepuh, ulama dan warga benda kerep.

${ }^{25}$ An interview with Kiai Miftah, The guidence of Pesantren Benda Kerep, on February 13td, 2016. at $10: 15 \mathrm{am}$.

26 An interview with Farihin, an allumnus of Pesantren Benda Kerep, on February 12nd, 2016. at $23: 50 \mathrm{am}$.
} 
house each day. To fully get all houses in Benda Kerep, it could take dozens of days to finish. That is such a social religious tradition flowering in Benda Kerep. The development of this unique tradition are historicly because of its demographic mobility and the blooming of the Benda Kerep citizens' economy.

2. The Demand To Wear Moslem Clothing

The clothing weared by santri Benda Kerep citizen must have been appropiate to the role of local tradition : wearing moslem clothings. The dress for man is remless cap and sarong, while the women should wear long-handed clothes and veil. For man especially, in the age of Kiai sholeh, it was relly forbiden to apply trousers since considered to be similiar to Ducth colonialist. Consequently, On every Friday prayer in mosque of Benda Kerep, each conggregant was demanded to use sarong which was also required to all guests visiting it to wear provided sarong and cap. Besides, it was said that in 1990s those who were unproperly dressed coming in the village would gain a slap from an unseen creature. That is why Kiai Faqih sometimes did not receive any guest unproperly wearing : not to dress sarong and remless cap.

However, today, visiting people not applying moslem clothing are allowed to come in even though they are not respected as those properly dressing sarong and cap. Furthermore students who do not wear a cap do not accept any reprimand as it did before. In short, the perpetuation of the culture of wearing-sarong and remless cap experiensed alternation since its appereance in very early age of Pesantren Benda Kerep up to the present. $^{27}$

3. Refusing Electronic Devices And To Make A Bridge

Regarding reconstruction of the bridge on the river of Benda Kerep and Benda Kulon, ${ }^{28}$ the guidances and people around Benda Kerep intensionally did not build it on the river in probably order to hide the village and its settlers from Ducth colonialist. With the result that people could live and do whorship peacefully and santris were quietly able to learn without the colonialist watching. The information is strengthened by simple but critic statement of Kiai Sholeh that the presence of a bridge would cause the acculturation of local and interurban culture which would make noise from sorts of vihcles like car and

\footnotetext{
27 An interview with Syatori, The citizen of Pesantren Benda Kerep, on February 22nd, 2015. at $09: 30 \mathrm{am}$.

${ }^{28}$ A village on the west side of Benda Kerep seperated by a river.
} 
motorcycle. It was distinctly about to disturb the composure and and absorption of santri and people of Benda kerep in conducting worship and learning. ${ }^{29}$

In 2006, one, in the name of Pesantren Benda Kerep, proposed an aid to construct a bridge. The proposal was granted by related instantion and it was going to make it real. However, the citizens and kiais of Benda kerep mostly rejected it. The project material having been carried eventually was used to build concrete heaps to accros nd embankment on the river side. Accordingly, some material as well as a heavy engine were brought by flood.

On the other point of view, the writer indicates that the existing of a bridge for Benda Kerep people would just make their economic machines disturbed. Considering at the first time of Cimeweuh opened for pesantren and village, people depended their lives on farming in rice field and hunting at the river. Eternality and sustainability of the river as well as the environment of Benda Kerep therfore became a priority, rather than building a bridge considered to crush their economic sources. Finally, inspite of the fact

29 An interview with nurrohman, a senior santri of Pesantren Benda Kerep, on January 21st, 2016. at $12: 30 \mathrm{am}$. that the bridge was not built but a concrete heap in 2011, people could come in and out Benda Kerep.

As a trditional pesantren guarding the wisdom tradition. Benda Kerep firstly forbid the electricity to come in this village whatever the reson was, yet by the time electric generator was used from 1986 to 1988 . It was followed by the effort of local government through the program Listrik Masuk Desa (the electricity comes in village) that electricity was accepted in the heart of Benda Kerep citizens in 1988. Nevertheless, it had only to be used as illumination at night and during the the prosess of learning.

The electricity in Benda Kerep also affect the modernsation of infrastructure there. It could be found that houses around Benda Kerep has imitated the modernized house styles. The progress on infrastructure after electricity came in, did not make the citizen dissapointed because they are convinced that the advancement of science and technology, being about to affect their pesantren, did not have to seen as the purpose of life itself. $^{30}$ Consequently, despite the fact that electricity and luxirious houses have decorated Benda Kerep, tradition

30 Zamakhsyari Dhofier, Tradisi Pesantren Studi Tentang Pandangan Hidup Kiyai, (Jakarta: LP3ES. Cet I, 1982), p.167. 
identity and commitment toward norms still became their priority scale.

\section{E. Conclusion}

Based on the result of the deep research and discussion on Historisity and tradition of Pesantren Benda Kerep in Argasunya, Harjamukti, Cirebon, it can be gained some following conclusions :

1. Social religious tradition : including the celebration of great islamic days such as : tradition of Maulid Prophet Muhammad, the obligation to wear moslem clothing for santri, kiai, citizen and even guests of Pesanten Benda Kerep.

2. Tradition of religious ritual: involving activities of tarekat syatariah for Kiai, and senior student as well as conducting riyadloh to all students, and

3. Silence tradition : it is as an effort to shelter students and citizens of Pesantren Benda Kerep from a nasty outside culture by refusing to build a bridge on their only traffic, and also impacted the banning of electronic devise utilizing like television, radio and sound speaker.

\section{Bibliography}

Books

Abdullah, Irwan. 2004 "Konstruksi dan Reproduksi kebudayaan," Yogyakarta : Pustaka Pelajar

Abdurrahman, Dudung, 1999. "Metode Penelitian Sejarah", Jakarta : Logos.

Ali, Mohamad. 1999. "Reorientasi Makna Pendidikan: Urgensi Pendidikan Terpadu", dalam Pesantren Masa Depan: Wacana Pemberdayaan dan Transformasi Pesantren, ed. Marzuki Wahid et. Al. Bandung: Pustaka Hidayah.

Azra, Azumardi. 1997. "Pesantren : Kontinuitas dan Perubahan", Pengantar dalam Nucholis Madjid, Bilik-Bilik Pesantren : Sebuah Potret Perjalanan". Jakarta : Paramida. "Pendidikan Islam Tradisi dan Modernisasi di Tengah Tantangan Milenium III," (Jakarta : Kencana Prenada Media Group, 2012)

Dhofier, Zamakhsyari. 1982. Tradisi Pesantren Studi Tentang Pandangan Hidup Kiyai, Cet I. Jakarta: LP3ES.

Dosen-dosen IAIN Syekh Nurjati Cirebon, 2014. "Pondok Pesantren di Wilayah III Cirebon," Yogyakarta : Kaukaba Dipantara.

Fadjar, Malik. 1998. "Visi Pembharuan

Pendidikan Islam". Jakarta: LP3N. 
Fathi, Mohammad Royyani dan Farid Wajdi, 2004. "Pesantren Buntet Melintas Sejarah,"'Cirebon : AnNur Press.

Francis M, Abraham, 1991. "Modern Di

Dunia Ketiga," Yogyakarta: PT. Mutiara Wacana yogya

Giddens,

Antthony, 2011.

"Konsekuensi-konsekuensi

Modernitas," Bantul : Kreasi

Wacana

Hasan, Ahmad Zaeni. 2000. "Perlawanan dari Tanah

Pengasingan Kiai Abbas,

Pesantren Buntet, dan Bela Negara." Jakarta: Elsas.

Hisyam Manshur, Mohammad, 1973 "Sekilas Lintas Buntet Pesantren Mertapada Kulon Cirebon", Buntet Pesantren Cirebon : Buntet Pesantren Press

Irianto, Bambang dan Fatimah, 2009. "Siti Syekh Nurjati (Syekh Dzatul Kahfi) Perintis Dakwah dan Pendidikan," Cirebon: STAIN Press

Masduqi, Zaenal, 2015. "Cirebon dalam sketsa ekonomi dan tradisi," Cirebon: Nurjati Press

Muchtarom, Zahairini, dkk. 2010. "Sejarah Pendidikan Islam." Jakarta: Bumi Aksara.

Muhaimin, A. G. 1995. The Islamic traditions of Cirebon : ibadat and adat among Javanese muslims, Canberra : ANU E Press.

Muhtarom H.M, 2005. "Reproduksi Ulama di Era Globalisasi
Resistansi Tradisional Islam," Yogyakarta : Pustaka Pelajar

Nafi' ah, Ilman. Dan Izzati, Nurma. dkk, 2014. "Pedoman penulisan proposal/skripsi". Cirebon : IAIN sejati press : CV. Pangger.

Pranowo, Bambang, 2011. "Memahami Islam Jawa," Jakarta: Pustaka Alvabet,Cetakan 2.

Qomar, Mujamil. 1996. "Pesantren Dari Transformasi Metodologi Menuju Demokratisasi Institusi." Jakarta: Erlangga.

Raharjo, Dawan. 1985. "Pergulatan Dunia Pesantren membangun dari bawah". Jakarta: P3M.

Sarwono, Sarlito Wirawan. 1995 "Teori-teori psikologi sosial". Jakarta : PT Raja grafindo persada.

Sulton, M. dan Khusnuridlo, M. 2006. "Manajemen Pondok Pesantren Dalam Prespektif Global".Yogyakarta: Laksbang PresSindo.

Syathori, A. 2012. "Modernisasi Pendidikan Di Pesantren (Studi Sistem Pendidikan Pesantren AlShighor Gedongan Kecamatan Pangenan Kabupaten Cirebon)". Cirebon: IAIN Syekh Nurjati.

Wahju, Amman N, 2010. "Sajarah Wali Syekh Syarif Hidayatullah Sunan Gunung Jati (Naskah Kuningan)," Bandung : PUSTAKA

Zaeni

Hasan,

Ahmad, 2000"Perlawanan Dari Tanah Pengasingan Kiai Abbas, 
Pesantren Buntet, dan Bela Negara," Jakarta: Elsas.

\section{Website}

http://cerianurrohmah.blogspot.com/201

2/11/sejarah-perjuangan-bangsaindonesia-dan.html. Oleh: Nur Rochmah. Diunduh 31 -5-2015.

\section{Interviews}

An interview with Kiai Miftah, The guidence of Pesantren Benda Kerep, on February 22nd, 2015. at $09: 30 \mathrm{am}$.

An interview with Kiai Miftah, The guidence of Pesantren Benda Kerep, on February 2nd, 2016. at $07: 45 \mathrm{pm}$.

An interview with Nurrohman, a senior student of Pesantren Benda
Kerep, on Januari 21st, 2016, at $00: 30 \mathrm{pm}$.

An interview with Muhammad, a citizen of Benda Kulon, on January 21st, 2016, at $01.15 \mathrm{pm}$.

An interview with Hamdan, a student of Pesantren Benda Kerep on February 12th, 201602.00 pm.

An interview with Farihin, an alumnus of Pesantren Benda Kerep, on February 12th, 201611.50 pm.

An interview with syatori, a citizen of Benda Kerep on February 12th, 2016 at $17.50 \mathrm{pm}$

An interview with Kiai Miftah, The guidence of Pesantren Benda Kerep on Februari 12th 2016 at $10.15 \mathrm{pm}$ 